\title{
Guillain-Barré Syndrome Following Viral Infections: Considerations for Future Treatment and Research
}

\author{
Lili Wang* \\ Department of Medicine, Division of Infectious Diseases, Icahn School of Medicine at Mount Sinai, New York, NY, USA
}

\begin{abstract}
As the world's population grows in an explosive way, the circumstances we live in become more crowed than ever in human history. Although medicine and biotechnology have developed tremendously in the new century, the growing density of population has brought us unexpected challenges in public health. This not only causes the emergence of new viruses but also makes coinfection and super-infection more common than previously (Table $\left.1^{1-14}\right)$. However, the symptoms of these infections, although severe and life threatening in extreme cases, share some common characteristics in outcomes. Many of them cause Guillain-Barré syndrome (GBS) and respiratory emergency. The case reported by Hariharan et al. ${ }^{15}$ has provided a good reference for the treatment outcomes of such conditions.
\end{abstract}

GBS is an autoimmune disorder, in which the immune system attacks the peripheral nervous system. It causes muscle weakness, due to damage to nerve cells and their supporting structures. ${ }^{16}$ Different types of GBS feature different types of immune attack. Although it is a relatively rare event, GBS could be life threatening, with bulbar and respiratory involvement. It is reported that in two-thirds of patients, neuropathic GBS occurs after an infection. ${ }^{17}$ GBS is a known sequelae of Dengue infection, ${ }^{18}$ and has been reported in influenza virus, herpesvirus and hepatitis virus infections, etc. ${ }^{16,19}$ Literally, any virus infection has the potential to cause GBS. Due to the rising pandemics of Zika virus in recent years, GBS has become a focus of discussion. In 2013-2014, GBS was reported from the areas of Zika virus outbreaks, and in 2015, reported again in Oceania and the Americas. Statistically, during Zika pandemics in French Polynesia, among 28,000 persons under medical care, $38(0.14 \%)$ patients developed GBS, compatible with the acute motor axonal neuropathy subtype of the disease. ${ }^{20}$

In recent years, virus-caused pandemics seem to have a trend of taking off, and the syndromes caused by these diseases have also showed some new and more complicating characteristics. One typical example is the reoccurrence of Zika virus. On its initial appearance in the $1950 \mathrm{~s}$, it seemed to be mild. ${ }^{21}$ As such, Zika virus infection was considered as benign throughout the 20th century. ${ }^{22}$ But, in the recent 2015 outbreak in Brazil, it was reported to be associated with GBS and microcephaly. ${ }^{23}$ Considering Dengue and Zika viruses are from the same Flavivirus family, it is not surprising that the symptoms of Zika infection are often confused with

Abbreviations: GBS, Guillain-Barré syndrome; PCT, percutaneous dilatational tracheostomy.

Received: October 9, 2017; Revised: February 9, 2018; Accepted: February 23, 2018

${ }^{*}$ Correspondence to: Lili Wang, Department of Medicine, Division of Infectious Diseases, Icahn School of Medicine at Mount Sinai, New York, NY, USA. E-mail: lili.wang@mssm.edu

How to cite this article: Wang L. Guillain-Barré Syndrome Following Viral Infections: Considerations for Future Treatment and Research. Exploratory Research and Hypothesis 2018;3(1):4-5. doi: 10.14218/ERHM.2017.00035.
Dengue virus infection and Dengue-chikingunya super-infections when causing GBS.

In all the cases reported for the 2013-2015 Zika virus breakouts, the infected persons showed mild fevers, headaches and body pains. These symptoms are very similar to those of Dengue and chikingunya infections, two other viral diseases that are often endemic in the same areas and are also transmitted by Aedes mosquitoes. Indeed, this may have caused many Zika infections to be mistaken as Dengue or chikingunya. Considering the possibilities of super-infections of multiple viruses, it is very difficult to confirm that the associated GBS is due to which viral infection(s). Even though the example provided by this case report has significant clinical magnificence (without associated thrombocytopenia), ${ }^{15}$ the complication is very similar to concurrent Zika virus infection. Under specific conditions that cause respiratory emergency, the treatment used in this case report can be applied to GBS induced by Zika virus infection.

Although GBS is a rare event in virus infection, the lethal consequence needs proper treatment and that's where we should provide corresponding care to the patients. In Table 1, the main viruses causing pandemics in recent years are listed. One thing worth noticing is that most of these viruses can cause GBS and/or respiratory emergency. As the emerging viruses like Zika virus have no proper vaccines to prevent infection, under a condition when there is a new virus pandemic without proper vaccines, the treatment of a severe lethal syndrome becomes the focus of emergency. This paper may provide some valuable references when coping with emerging viruses that can cause GBS and/or respiratory emergency.

Traditionally, the method to treat respiratory emergency usually involves surgical tracheostomy. In this case, percutaneous dilatational tracheostomy (PCT) was performed instead of classical tracheostomy. Compared to the old method, PCT has a smaller size of incision and quicker recovery. Also, PCT is supposed to be a bedside procedure that can be performed by every physician, ${ }^{24}$ with less assistance and material. ${ }^{25}$ These traits fit the requirements when there is a breakout of viruses and large numbers of patients need to be taken care of. PCT could be a potential lifesaving method when facing certain future emerging virus attacks that cause respiratory emergency. Another critical method used in this case report is IV-Ig immune therapy. Based on the response of the patients while the treatments were going on, it is clear that IV-Ig here plays a key role in the patient's recovery. However, this is not surprising, for IV-Ig immune therapy is already a routine method to treat GBS clinically.

In summary, although this case report provided a specific condition of combined chikungunya and Dengue infection, it could become very typical in future virus pandemics. The successful treatment of this condition provided valuable reference for emerging virus pandemics that may require a similar treatment for GBS and life-threatening breathing problems. 
Wang L. Treat GBS caused by viral infection

Table 1. Recent virus pandemics and their relationship to Guillain-Barré syndrome and respiratory distress syndrome

\begin{tabular}{|c|c|c|c|}
\hline Outbreaks & Year & $\begin{array}{l}\text { May cause Guillain-Barré } \\
\text { syndrome }\end{array}$ & $\begin{array}{l}\text { May cause respiratory } \\
\text { distress syndrome }\end{array}$ \\
\hline Severe acute respiratory syndrome & $2002-2003$ & Unknown & Yes $^{1}$ \\
\hline Chikungunya & 2006 & Yes $^{2}$ & Yes $^{3}$ \\
\hline Zika virus in Yap Island, Federated States of Micronesia & 2007 & Yes $^{4}$ & Unknown \\
\hline H1N1 influenza & 2009-2010 & $Y_{e s}^{5}$ & Yes $^{6}$ \\
\hline Measles in Congo & 2010-now & Unknown & Yes $^{7}$ \\
\hline Middle East respiratory syndrome & 2012-now & Unknown & Yes $^{8}$ \\
\hline Zika virus in French Polynesia & 2013-2014 & Yes $^{9}$ & Yes $^{10}$ \\
\hline Chikungunya & 2013-now & Yes $^{2}$ & Yes $^{3}$ \\
\hline Ebola in West Africa & 2013-now & Unknown & Yes $^{11}$ \\
\hline Zika virus in Brazil and Colombia & 2015-now & Yes $^{12}$ & Yes $^{10}$ \\
\hline Dengue fever in Hawaii and tropical Asian islands & $2015,2017-$ now & Yes $^{13}$ & Yes $^{14}$ \\
\hline
\end{tabular}

\section{References}

[1] Lew TW, Kwek TK, Tai D, Earnest A, Loo S, Singh K, et al. Acute respiratory distress syndrome in critically ill patients with severe acute respiratory syndrome. JAMA 2003;290(3):374-380. doi:10.1001/ jama.290.3.374.

[2] Oehler E, Fournier E, Leparc-Goffart I, Larre P, Cubizolle S, Sookhareea $C$, et al. Increase in cases of Guillain-Barré syndrome during a Chikungunya outbreak, French Polynesia, 2014 to 2015. Euro Surveill 2015;20(48):30079. doi:10.2807/1560-7917.ES.2015.20.48.30079.

[3] Singh A. Acute Respiratory Distress Syndrome: An Unusual Presentation of Chikungunya Fever Viral Infection. J Glob Infect Dis 2017;9(1):33-34. doi:10.4103/0974-777X.194374.

[4] Craig AT, Butler MT, Pastore R, Paterson BJ, Durrheim DN. Acute flaccid paralysis incidence and Zika virus surveillance, Pacific Islands. Bull World Health Organ 2017;95(1):69-75. doi:10.2471/BLT.16.171892.

[5] Wise ME, Viray M, Sejvar JJ, Lewis P, Baughman AL, Connor W, et al. Guillain-Barré syndrome during the $2009-2010$ H1N1 influenza vaccination campaign: population-based surveillance among 45 million Americans. Am J Epidemiol 2012;175(11):1110-1119. doi:10.1093/ aje/kws196.

[6] Fouchier RA, Schneeberger PM, Rozendaal FW, Broekman JM, Kemink SA, Munster V, et al. Avian influenza A virus (H7N7) associated with human conjunctivitis and a fatal case of acute respiratory distress syndrome. Proc Natl Acad Sci U S A 2004;101(5):1356-1361. doi:10.1073/pnas.0308352100.

[7] Piastra M, Onesimo R, De Luca D, Lancella L, Marzano L, De Rosa G, et al. Measles-induced respiratory distress, air-leak and ARDS. Eur J Clin Microbiol Infect Dis 2010;29(2):181-185. doi:10.1007/s10096009-0838-x.

[8] Bush NE, Wheeler WM. Personal technology use by U.S. military service members and veterans: an update. Telemed J E Health 2015;21(4):245-258. doi:10.1089/tmj.2014.0100.

[9] Cao-Lormeau VM, Blake A, Mons S, Lastere S, Roche C, Vanhomwegen J, et al. Guillain-Barré Syndrome outbreak associated with Zika virus infection in French Polynesia: a case-control study. Lancet 2016;387(10027):1531-1539. doi:10.1016/S0140-6736(16)00562-6.

[10] Arzuza-Ortega L, Polo A, Perez-Tatis G, Lopez-Garcia H, Parra E, Pardo-Herrera LC, et al. Fatal sickle cell disease and Zika virus infection in girl from Colombia. Emerg Infect Dis 2016;22(5):925-927. doi:10.3201/eid2205.151934.

[11] Mora-Rillo M, Arsuaga M, Ramirez-Olivencia G, de la Calle F, Borobia $A M$, Sanchez-Seco $P$, et al. Acute respiratory distress syndrome after convalescent plasma use: treatment of a patient with Ebola virus disease contracted in Madrid, Spain. Lancet Respir Med 2015;3(7):554-
562. doi:10.1016/S2213-2600(15)00180-0.

[12] Oehler E, Watrin L, Larre P, Leparc-Goffart I, Lastere S, Valour F, et al. Zika virus infection complicated by Guillain-Barre syndromecase report, French Polynesia, December 2013. Euro Surveill 2014;19(9):pii20720. doi:10.2807/1560-7917.ES2014.19.9.20720.

[13] Soares CN, Cabral-Castro M, Oliveira C, Faria LC, Peralta JM, Freitas $\mathrm{MR}$, et al. Oligosymptomatic dengue infection: a potential cause of Guillain Barre syndrome. Arq Neuropsiquiatr 2008;66(2A):234-237. doi:10.1590/S0004-282X2008000200018.

[14] Yeh CY, Chen PL, Chuang KT, Shu YC, Chien YW, Perng GC, et al. Symptoms associated with adverse dengue fever prognoses at the time of reporting in the 2015 dengue outbreak in Taiwan. PLoS Negl Trop Dis 2017;11(12):e0006091. doi:10.1371/journal.pntd.0006091.

[15] Hariharan U, Chaudhary L, Bhasin N. Guillain-Barre syndrome following combined chikungunya and dengue infection: critical care management and future research. Explor Res Hypothesis Med 2017;2(1):30-32. doi:10.14218/erhm.2017.00001.

[16] Yuki N, Hartung HP. Guillain-Barré syndrome. N Engl J Med 2012;366(24):2294-2304. doi:10.1056/NEJMra1114525.

[17] Hughes RA, Cornblath DR. Guillain-Barré syndrome. Lancet 2005;366(9497):1653-1666. doi:10.1016/S0140-6736(05)67665-9.

[18] Carod-Artal FJ, Wichmann O, Farrar J, Gascon J. Neurological complications of dengue virus infection. Lancet Neurol 2013;12(9):906919. doi:10.1016/S1474-4422(13)70150-9.

[19] Lehmann HC, Hartung HP, Kieseier BC, Hughes RA. Guillain-Barré syndrome after exposure to influenza virus. Lancet Infect Dis 2010;10(9):643-651. doi:10.1016/S1473-3099(10)70140-7.

[20] Petersen LR, Jamieson DJ, Powers AM, Honein MA. Zika virus. N Engl J Med 2016;374(16):1552-1563. doi:10.1056/NEJMra1602113.

[21] Dick GW. Zika virus. II. Pathogenicity and physical properties. Trans R Soc Trop Med Hyg 1952;46(5):521-534. doi:10.1016/00359203(52)90043-6.

[22] Grossi-Soyster EN, LaBeaud AD: Clinical aspects of Zika virus. Curr Opin Pediatr. 2017;29(1):102-106. doi:10.1097/MOP.0000000000000449.

[23] Sikka V, Chattu VK, Popli RK, Galwankar SC, Kelkar D, Sawicki SG, et al. The emergence of zika virus as a global health security threat: A review and a consensus statement of the INDUSEM Joint Working Group (JWG). J Glob Infect Dis 2016;8(1):3-15. doi:10.4103/0974$777 X .176140$.

[24] Friedman $Y$, Mayer AD. Bedside percutaneous tracheostomy in critically ill patients. Chest 1993;104(2):532-535. doi:10.1378/ chest.104.2.532.

[25] Barba CA, Angood PB, Kauder DR, Latenser B, Martin K, McGonigal $\mathrm{MD}$, et al. Bronchoscopic guidance makes percutaneous tracheostomy a safe, cost-effective, and easy-to-teach procedure. Surgery 1995;118(5):879-883. doi:10.1016/S0039-6060(05)80279-X. 